\title{
Emergence and Control of Rottboelia spp. In Different Months In Sugarcane Cultivation ${ }^{1}$
}

\author{
Emergência e Controle de Rottboelia spp. em Diferentes Meses na Cultura da Cana-de-Açúcar
}

\author{
INOUE, M.H. ${ }^{2}$, MERTENS, T.B. ${ }^{2}$, MENDES, K.F. ${ }^{3}$, CONCIANI, P.A. ${ }^{3}$, SANTOS, F.S. ${ }^{2}$, and \\ FERREIRA, D.G. ${ }^{2}$
}

\begin{abstract}
This study aimed to evaluate the control of Rottboelia spp. with the formulated mixture diuron + hexazinone + sulfometuron-methyl and the emergence of this weed in the months of April, May, June, July, August, September, October and November 2012 in sugarcane cultivation, cultivar RB867515. The experimental design consisted of randomized blocks, with treatments in a $4 \times 4$ factorial arrangement with four replicates for the months of April to November. The emergence tests used a randomized block design, in a $8 \times 5$ split plot arrangement with four replicates. The analyzed factors were the rates of the formulated mixture (diuron + hexazinone + sulfometuron-methyl), which consisted of: 1,809.00+510.00 $+43.50 \mathrm{~g} \mathrm{ha}^{-1}$ (T2); $1,507.50+425.00+36.25 \mathrm{~g} \mathrm{ha}^{-1}$ (T3) and 1,386.90 + 391.00 + 33.35 $\mathrm{g} \mathrm{ha}^{-1}$ (T4), in addition to the control (T1) without application. Controls over $80.00 \%$ were found for the application performed in the month of November in evaluations at 30 and 60 DAA, regardless of the rate in use. All treatments were selective for the sugarcane cultivar RB867515. The tests conducted in the months of August, September, October and November showed the highest population density.
\end{abstract}

Keywords: R. exaltata, rates, effectiveness, Saccharum spp.

\begin{abstract}
RESUMO - Objetivou-se neste estudo avaliar o controle de Rottboelia spp. com a mistura formulada diuron + hexazinone + sulfometuron-methyl e a emergência dessa planta daninha nos meses de abril, maio, junho, julho, agosto, setembro, outubro e novembro de 2012 na cultura da cana-deaçúcar, variedade RB867515. Utilizou-se o delineamento em blocos casualizados, com os tratamentos dispostos em esquema fatorial $4 \times 4$, com quatro repetições para os meses de abril a novembro. Nos ensaios de emergência utilizou-se o delineamento de blocos casualizados, em esquema de parcelas subdivididas $8 \times 5$, com quatro repetições. Os fatores analisados foram as doses da mistura formulada (diuron + hexazinone + sulfometuron-methyl), que consistiram em: 1.809,00 + 510,00 + 43,50 $\mathrm{g} \mathrm{ha}^{-1}$

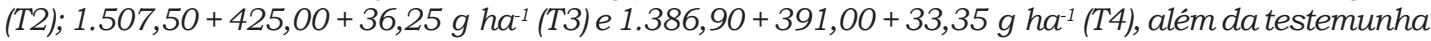
(T1) sem aplicação. Controles superiores a 80,00\% foram verificados para a aplicação realizada no mês de novembro nas avaliações aos 30 e 60 DAA, independentemente da dose utilizada. Todos os tratamentos foram seletivos para a variedade RB867515 de cana-de-açúcar. Os ensaios instalados nos meses de agosto, setembro, outubro e novembro registraram a maior densidade populacional.
\end{abstract}

Palavras-chave: capim-camalote, doses, eficácia, Saccharum spp.

\section{INTRODUCTION}

In recent years, sugarcane has become particularly important in Brazil because it is used in the production of ethanol and sugar; thus, it is an important renewable source of energy (Meschede et al., 2011; Galon et al., 2012). However, some factors limit the expression of the productive potential of sugarcane (Galon et al., 2012), e.g., weed interference.

Recebido para publicação em 22.1.2015 e aprovado em 18.12.2015.

2 Universidade do Estado de Mato Grosso, Tangará da Serra-MT, Brasil, < miriamhinoue@hotmail.com $>$; ${ }^{3}$ Universidade de São Paulo, Centro de Energia Nuclear na Agricultura, Piracicaba-SP, Brasil. 
According to Oliveira \& Freitas (2008), itchgrass (Rottboelia exaltata) is one of the various weed species that cause damage to sugarcane crops, and it is actually becoming the most harmful one because it is prolific, has high vigor, and spreads easily.

Carvalho et al. (2005) reported that $R$. exaltata has vigorous vegetative growth and a rapid reproductive cycle. Studies carried out by these authors found that at 49 days after sowing (DAS) it began flowering and, as a result, seed production started as well. This is still a very vigorous species as regards occupation of space and rapid growth; it is capable of emitting reproductive structures and produce seedlings throughout its cycle. The control of this weed plant must be based on knowledge of growth and development of the species, especially in the initial phase, because flowering may occur after that, with rapid dispersion of seeds to soil (Carvalho et al., 2005).

Among management practices, chemical control is the most frequently used in plantations, especially because it is a practical, highly efficient and quick method. However, herbicides must have a long residual effect on the soil in order to control the flow of weed emergence in the area (Tironi et al., 2013), and wide spectrum of control to suit the demands of the crop; in this respect, herbicide mixtures that meet these criteria are extremely important (Santos et al., 2011). In this sense, the formulated mixture diuron + hexazinone + sulfometuron-methyl is an option for weed management in sugarcane crops. The herbicide diuron belongs to the chemical group of sulphonylureas, and hexazinone, to that of triazines; they both operate in photosystem II, inhibiting the process of photosynthesis (Oliveira Jr., 2011).

According to Belt \& milk (2012), the sulfometuron-methyl is one of the herbicides most frequently used as a ripening agent in sugarcane crops. In addition to sugarcane cultivation, these authors found that the use of this herbicide at the rate of $7.5 \mathrm{~g} \mathrm{ha}^{-1}$ was selective for peanuts, whereas the rates of 7.5 and $15 \mathrm{~g} \mathrm{ha}^{-1}$ were selective for coffee, citrus, cassava and rubber crops.

However, there are few data on the association of the herbicides diuron + hexazinone + sulfometuron-methyl, especially as regards the performance of this product in the control of Rottboelia spp. Also, there is no concrete information about the months of the year when the infestation of this weed is more intense in sugarcane crops in the state of Mato Grosso, Brazil.

Thus, this study aimed to evaluate the control of Rottboelia spp. with the formulated mixture diuron + hexazinone + sulfometuronmethyl and the flow of emergence of this weed in the months of April, May, June, July, August, September, October and November 2012 in the cultivation of sugarcane, cultivar RB867515.

\section{MATERIAL AND METHODS}

The tests were performed on the farm Fazenda Pezzini in the municipality of Tangará da Serra - MT (14²1'59.1" S and 5332'45.8" W). The test area has been cultivated with sugarcane (cultivar RB867515) for four years and has high infestation of R. exaltata (> 68 plants $\left.\mathrm{m}^{2}\right)$.

The test was first performed on the sugarcane harvest, and Rottboelia spp. plants present in the area have been desiccated with diquat (300 $\left.\mathrm{g} \mathrm{ha}^{-1}\right)$ applied with a direct sprayer, aiming to simulate pre-emergence conditions. The formulated mixture diuron + hexazinone + sulfometuron-methyl was applied on April 10th, 2012, seven days after cleaning the area and desiccating the plants of Rottboelia spp. At other application times (May, June, July, August, September, October and November 2012) the same methodology was followed. The tests were completed on March 10th, 2013; when there was the last evaluation on the application made in November. The plots measured $6.5 \times 10.0 \mathrm{~m}$, totaling $65.0 \mathrm{~m}^{2}$.

The experimental design consisted of randomized blocks, with treatments organized in a $4 \times 4$ factorial arrangement with four replicates for the months of April to November. The analyzed factors were the rates of the formulated mixture (diuron + hexazinone + sulfometuron-methyl), which consisted of: $1,809.00+510.00+43.50 \mathrm{~g} \mathrm{ha}^{-1}$ (T2); $1,507.50$ $+425.00+36.25 \mathrm{~g} \mathrm{ha}^{-1}$ (T3) and $1,386.90+$ $391.00+33.35 \mathrm{~g} \mathrm{ha}^{-1}(\mathrm{~T} 4)$, and also the control without application (T1) and the evaluation 
times, at 30, 60, 90 and 120 days after application (DAA).

The emergency test used a randomized block design, in a $8 \times 5$ split plot arrangement with four replicates. The plots refer to months of evaluation - April, May, June, July, August, September, October and November 2012 - and the subplots, to the times of emergence of Rottboelia spp. at 45, 60, 75, 90 and 120 days after desiccation (DAD).

The applications of the herbicide treatments were made with a $\mathrm{CO}_{2}$-pressurized backpack sprayer fitted with four XR110.02 flat fans, with pressure of $2.0 \mathrm{kgf} \mathrm{cm}^{-2}$, providing the equivalent of $200 \mathrm{~L} \mathrm{ha}^{-1}$, so that the application was positioned at $0.5 \mathrm{~m}$ above the ground surface. Information on weather conditions during the implementation of the experiment was provided by AGRITEMPO (Agrometeorological Monitoring System, 2013) and is shown in Figure 1.

In the control tests, evaluations of the plots were performed visually, and control of weed infestation and crop phytotoxicity was performed at 30, 60, 90 and 120 days after application (DAA). A scale was used, with scores ranging from $0 \%$ (zero) to 100\% (one hundred), where 0 indicates the absence of weed control or phytotoxicity and 100, the death of all specimens (SBCPD, 1995). The data were submitted to analysis of variance, and adjusted by regression equations $(p<0.05)$ by the F-test.

For the emergence test, the analyzed variables were the population density of emerged Rottboelia spp. plants, height and development stage of the plants present in the area of each plot. The evaluations were made at $45,60,75,90$ and 120 days after desiccation (DAD) for each month.

Population density of Rottboelia spp. plants was quantified by using a metal template measuring $1.0 \mathrm{~m}^{2}$, which was randomly thrown three times in each experimental plot (Oliveira \& Freitas, 2008). Plant height was assessed with a scaled tape measure (in meters) by measuring from the base (close to the ground level) to the apex. For this reason, ten plants were randomly sampled per plot, and they were evaluated until 120 DAD.

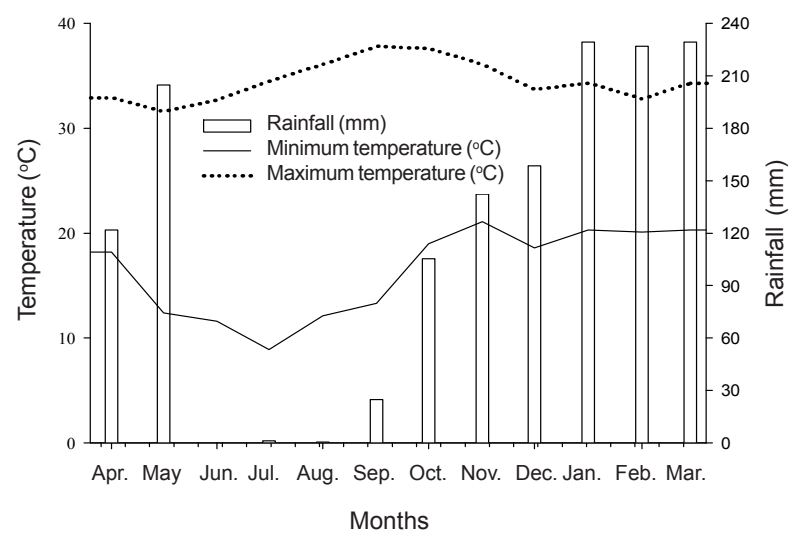

Figure 1 - Monthly data on maximum and minimum temperature and rainfall during the months of April 2012 to March 2013. Tangará da Serra, MT. Harvest 2012/2013.

Phenological stage was determined with the $\mathrm{BBCH}$ scale, where grades were assigned based on numbers ranging from 0 to 9, according to Hess et al. (1997) (Table 1); the plants were subsequently identified when the phenological stage reached $50 \%+1$ of plants with a given growth feature (Carvalho et al., 2005).

Table 1 - BBCH scale for description of weeds based on the scores assigned to the vegetative stages of Rottboelia spp.

\begin{tabular}{|c|l|}
\hline $\begin{array}{c}\text { BBCH } \\
\text { Scale* }\end{array}$ & \multicolumn{1}{|c|}{ Description } \\
\hline 0 & Germination/sprouting \\
\hline 1 & Leaf development (main stem) \\
\hline 2 & Formation of side shoots/tillering \\
\hline 3 & Stem elongation or shoot development \\
\hline 4 & Vegetative propagation/ "Booting" (main shoot) \\
\hline 5 & Inflorescence emergence (main stem)/heading \\
\hline 6 & Flowering \\
\hline 7 & Development of fruit \\
\hline 8 & Ripening of fruit and seed \\
\hline 9 & Senescence, beginning of dormancy \\
\hline
\end{tabular}

* Hess et al. (1997).

The data were submitted to variance analysis and the means were compared by the Scott-Knott test $(\mathrm{p}<0.05)$.

\section{RESULTS AND DISCUSSION}

Figure 2 shows the results for control of Rottboelia spp. for the applications in the 


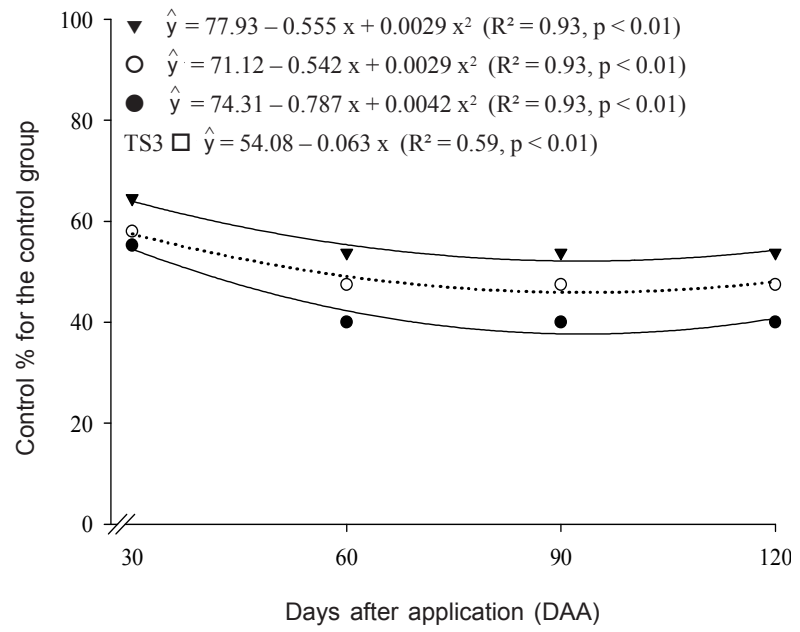

Rates: $1,809.00+510.00+43.50 \mathrm{~g} \mathrm{ha}^{-1}(\boldsymbol{\nabla}) ; 1,507.50+425.00+$ $36.25 \mathrm{~g} \mathrm{ha}^{-1}(\mathrm{O})$ and $1,386.90+391.00+33.35 \mathrm{~g} \mathrm{ha}^{-1}(\bullet)$.

Figure 2 - Control percentage of Rottboelia spp. for the control, evaluated at 30,60,90 and 120 DAA of different rates of the formulated mixture diuron + hexazinone + sulfometuronmethyl, for the experiment set up in the month of April.

month of April, where it appears that the use of rates of $1,809.00+510.00+43.50 \mathrm{~g} \mathrm{ha}^{-1}$, $1,507.50+425.00+36.25 \mathrm{~g} \mathrm{ha}^{-1}$ and $1,386.90$ $+391.00+33.35 \mathrm{~g} \mathrm{ha}^{-1}$ provided levels above $55.00 \%$ in the evaluation performed at 30 DAA. At 60, 90 and 120 DAA, control was below $54.00 \%$ regardless of the rate in use (Figure 2). By contrast, Toledo et al. (2012) found levels of 98.00 and $100.00 \%$ at 90 and 120 DAA, respectively, in the control of Panicum maximum with the use of diuron + hexazinone + sulfometuron-methyl $(1.386,90+391.00+$ $\left.33.35 \mathrm{~g} \mathrm{ha}^{-1}\right)$, in the sugarcane crop, cultivar RB 855453.

In the application held in the month of May, the rates of $1,507.50+425.00+36.25 \mathrm{~g} \mathrm{ha}^{-1}$ and $1,386.90+391.00+33.35 \mathrm{~g} \mathrm{ha}^{-1}$ provided levels of 40.00 and $37.50 \%$ of control at 30 DAA, respectively. In this same evaluation, the rate of $1,809.00+510.00+43.50 \mathrm{~g} \mathrm{ha}^{-1}$ provided $52.50 \%$ control of Rottboelia spp. In the assessments made at 60, 90 and 120 DAA, the control was higher than $62.00 \%$ with the use of different rates (Figure 3).

In the application held in the month of June, the assessments made at 30, 60 and 90 DAA showed that there was no emergence of Rottboelia spp. (Figure 4), due to the absence

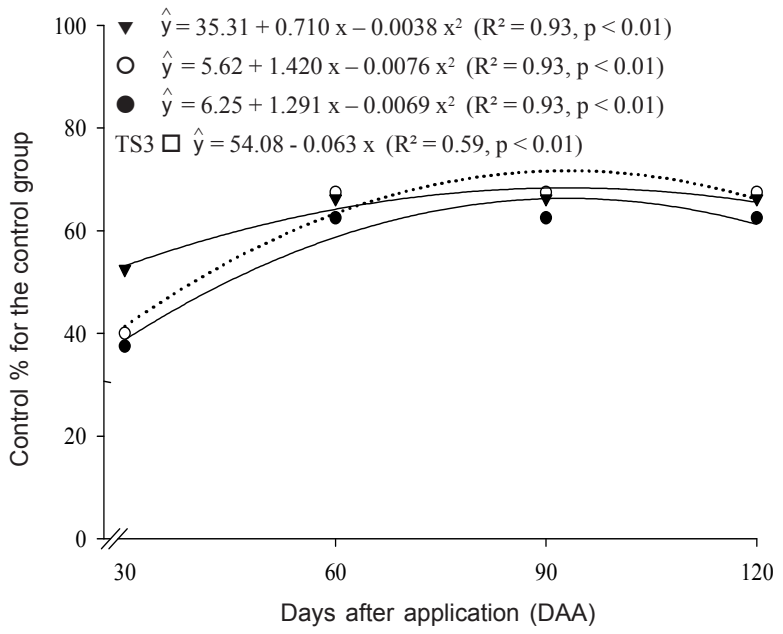

Rates: $1,809.00+510.00+43.50 \mathrm{~g} \mathrm{ha}^{-1}(\boldsymbol{\nabla}), 1,507.50+425.00+$ $36.25 \mathrm{~g} \mathrm{ha}^{-1}(\mathrm{O})$ and $1,386.90+391.00+33.35 \mathrm{~g} \mathrm{ha}^{-1}(\mathbf{O})$.

Figure 3 - Control percentage of Rottboelia spp. for the control, evaluated at 30,60,90 and 120 DAA of different rates of the formulated mixture diuron + hexazinone + sulfometuronmethyl, for the experiment set up in the month of May.

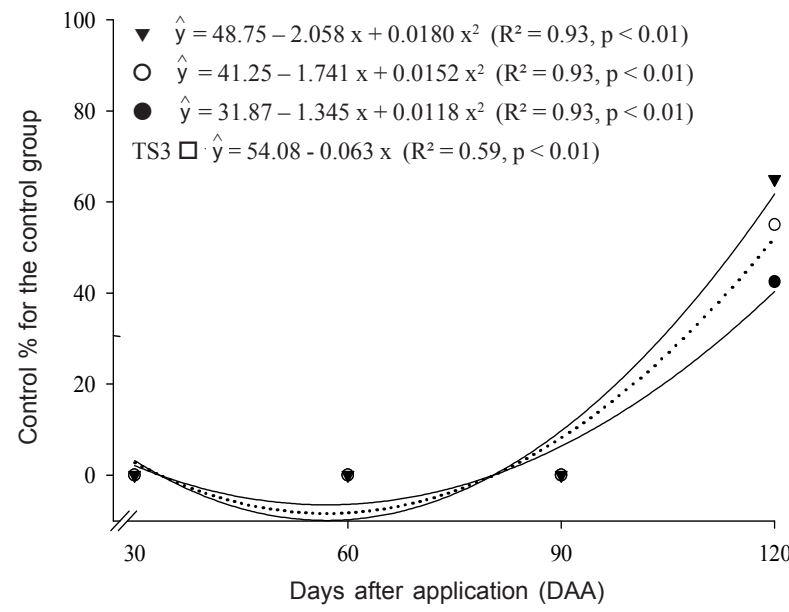

Rates: $1,809.00+510.00+43.50 \mathrm{~g} \mathrm{ha}^{-1}(\boldsymbol{\nabla}), 1,507.50+425.00+$ $36.25 \mathrm{~g} \mathrm{ha}^{-1}(\mathrm{O})$ and $1,386.90+391.00+33.35 \mathrm{ha}^{-1}(\bullet)$.

Figure 4 - Control percentage of Rottboelia spp. for the control, evaluated at 30,60, 90 and 120 DAA of different rates of the formulated mixture diuron + hexazinone + sulfometuronmethyl, for the experiment set up in the month of June.

of rainfall (Figure 1) in the region of Tangará da Serra - MT, which presents variability, with two defined seasons: a dry season from May to September, and a rainy season from October to April; however, the most critical months are June, July and August (Dallacort et al., 2011). 
In the evaluation performed at 120 DAA, Rottboelia spp. was present, and the use of rates of $1,809.00+510.00+43.50 \mathrm{~g} \mathrm{ha}^{-1}$, $1,507.50+425.00+36.25 \mathrm{~g} \mathrm{ha}^{-1}$ and $1,386.90$ $+391.00+33.35 \mathrm{~g} \mathrm{ha}^{-1}$ provided $65.00,55.00$ and $42.50 \%$ of control, respectively (Figure 4 ).

Figure 5 shows that in the month of July, at 30 and 60 DAA, there was no germination of Rottboelia spp., given the low levels of rainfall (Figure 1). Similarly, Gomes et al. (2012) also found absence of emergence of Rottboelia exaltata at 32 DAA because of the dry period of the region, which made prevented germination and/or establishment of emerged seedlings.

In the evaluation performed at 90 DAA, there was emergence of Rottboelia spp. plants, and control levels were higher than $40.00 \%$ with application of the rates of $1,809.00+510.00+43.50 \mathrm{~g} \mathrm{ha}^{-1}, 1,507.50+$ $425.00+36.25 \mathrm{~g} \mathrm{ha}^{-1}$ and $1,386.90+391.00+$ $33.35 \mathrm{~g} \mathrm{ha}^{-1}$. However, levels increased at 120 DAA, but they did not exceed $75.00 \%$ control for Rottboelia spp. (Figure 5).

In the application held in the month of August, it was found that the different rates of the formulated mixture provided control below $25.00 \%$ in the evaluation at $30 \mathrm{DAA}$. At $60 \mathrm{DAA}$, the rate of $1,809.00+510.00+43.50 \mathrm{~g} \mathrm{ha}^{-1}$ provided the most control for Rottboelia spp., $71.25 \%$. In the assessments performed at 90 and 120 DAA, the use of different rates provided control below $40.00 \%$ for Rottboelia spp. (Figure 6).

The application held in the month of September with the rate of $1,809.00+510.00$ $+43.50 \mathrm{~g} \mathrm{ha}^{-1}$ provided a higher level of control $(60.00 \%)$ at 30 DAA. At 60, 90 and 120 DAA, the control levels were lower than $30.00 \%$, regardless of the rate in use (Figure 7 ).

For the application performed in the month of October, it was found that the rate of $1,809.00+510.00+43.50 \mathrm{~g} \mathrm{ha}^{-1}$ provided a higher level of control $(32.50 \%)$ for Rottboelia spp. Levels below $8.00 \%$ were found at 60, 90 and 120 DAA, with the use of different rates (Figure 8 ).

Levels of control above $80.00 \%$ were found for the application performed in the month of November, in evaluations at 30 and

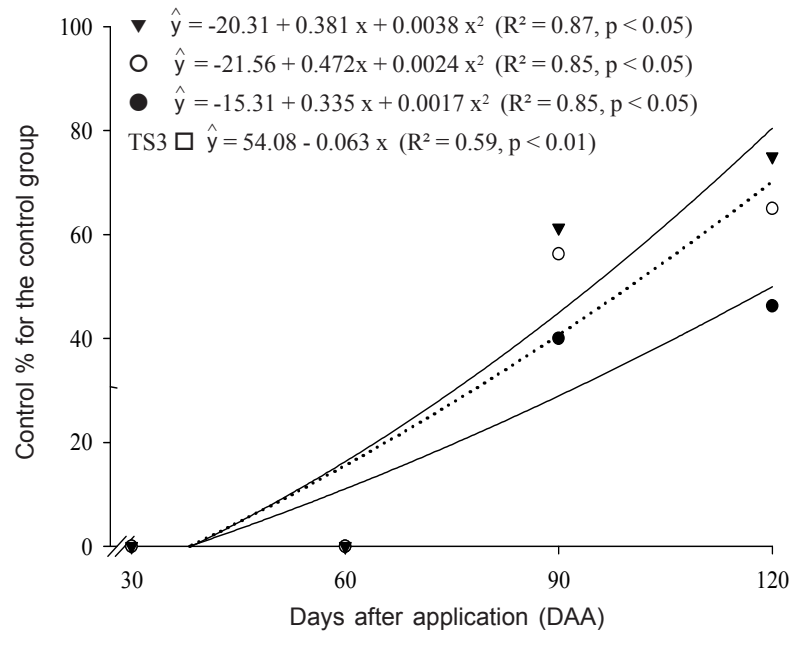

Rates: $1,809.00+510.00+43.50 \mathrm{~g} \mathrm{ha}^{-1}(\boldsymbol{\nabla}), 1,507.50+425.00+$ $36.25 \mathrm{~g} \mathrm{ha}^{-1}(\mathrm{O})$ and $1,386.90+391.00+33.35 \mathrm{~g} \mathrm{ha}^{-1}(\mathbf{O})$.

Figure 5 - Control percentage of Rottboelia spp. for the control, evaluated at 30,60, 90 and 120 DAA of different rates of the formulated mixture diuron + hexazinone + sulfometuronmethyl, for the experiment set up in the month of July.

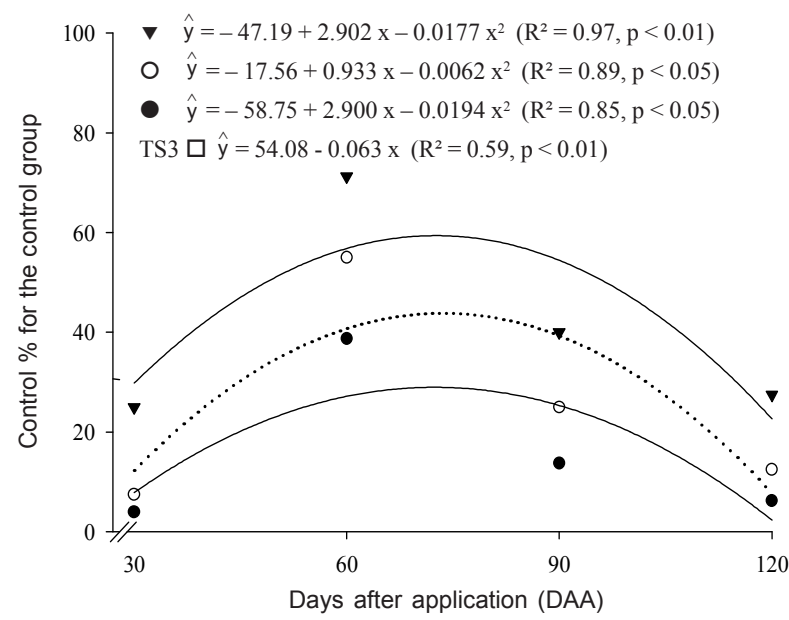

Rates: $1,809.00+510.00+43.50 \mathrm{~g} \mathrm{ha}^{-1}(\mathbf{\nabla}), 1,507.50+425.00+$ $36.25 \mathrm{~g} \mathrm{ha}^{-1}(\mathrm{O})$ and $1,386.90+391.00+33.35 \mathrm{~g} \mathrm{ha}^{-1}(\bullet)$.

Figure 6 - Control percentage of Rottboelia spp. for the control, evaluated at 30,60,90 and 120 DAA of different rates of the formulated mixture diuron + hexazinone + sulfometuronmethyl, for the experiment set up in the month of August.

60 DAA, regardless of the rate in use. In the assessments made at 90 and 120 DAA, levels were lower, but higher than $67 \%$ of control with the different rates of the formulated mixture (Figure 9). Toledo et al. (2010) found levels of $100.00 \%$ for the control of 


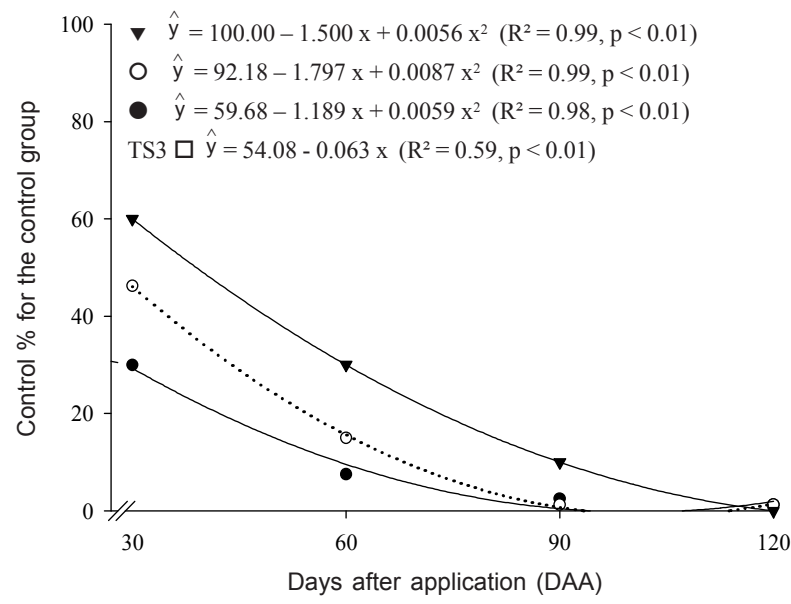

Rates: $1,809.00+510.00+43.50 \mathrm{~g} \mathrm{ha}^{-1}(\boldsymbol{\nabla}), 1,507.50+425.00+$ $36.25 \mathrm{~g} \mathrm{ha}^{-1}(\mathrm{O})$ and $1,386.90+391.00+33.35 \mathrm{~g} \mathrm{ha}^{-1}(\bullet)$.

Figure 7 - Control percentage of Rottboelia spp. for the control, evaluated at 30, 60, 90 and 120 DAA of different rates of the formulated mixture diuron + hexazinone + sulfometuronmethyl, for the experiment set up in the month of September.

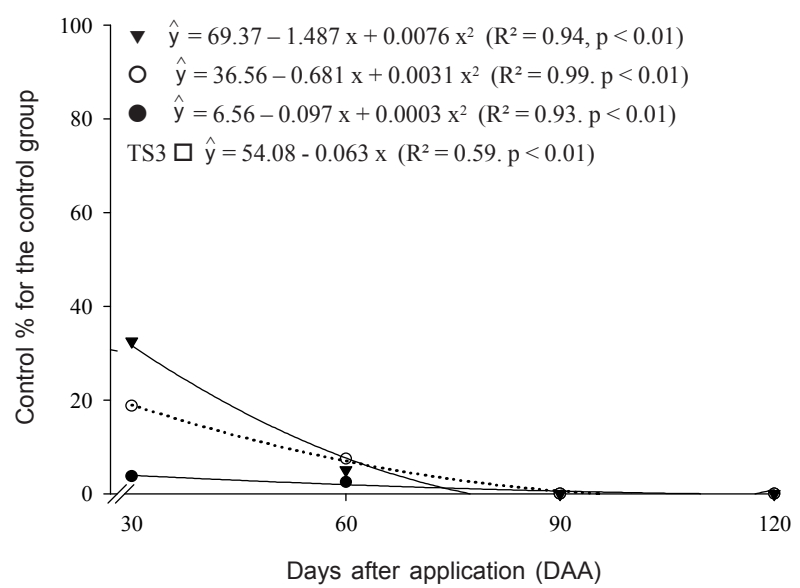

Rates: $1,809.00+510.00+43.50 \mathrm{~g} \mathrm{ha}^{-1}(\boldsymbol{\nabla}), 1,507.50+425.00+$ $36.25 \mathrm{~g} \mathrm{ha}^{-1}(\mathrm{O})$ and $1,386.90+391.00+33.35 \mathrm{~g} \mathrm{ha}^{-1}(\bullet)$.

Figure 8 - Control percentage of Rottboelia spp. for the control, evaluated at 30,60,90 and 120 DAA of different rates of the formulated mixture diuron + hexazinone + sulfometuronmethyl, for the experiment set up in the month of October.

Digitaria spp., Panicum maximum and Urochloa decumbens with use of diuron + hexazinone + sulfometuron-methyl $(1,386.90+391.00+$ $33.35 \mathrm{~g} \mathrm{ha}^{-1}$ ) at 30, 60 and 120 DAA, with the cultivar SP 801842.

Planta Daninha, Viçosa-MG, v. 34, n. 2, p. 229-238, 2016
The excellent control of Rottboelia spp. in the last month of application (November), in comparison with the previous months, can be attributed to the increase of rainfall (average of $142.2 \mathrm{~mm}$ ), unlike what had happened in the previous months (Figure 1).

With regard to selectivity of the sugarcane crop, in applications performed in May, June and July, phytotoxicity levels were lower than $2.00 \%$ at $30,60,90$ and $120 \mathrm{DAA}$, regardless of the rate in use. In the other months, phytotoxicity levels were lower than those of May, June and July (Figure 10). Similar results to those in the present study were found by Toledo et al. (2012). These authors have found that the use of diuron + hexazinone + sulfometuron-methyl $(1,386.90+391.00+$ $33.35 \mathrm{~g} \mathrm{ha}^{-1}$ ) at 30,60 and 90 DAA did not cause phytotoxicity in the sugarcane crop, cultivar RB 855453.

Figure 11 shows that, at 45 days after desiccation (DAD), Rottboelia spp. plants, in the months of April and May, were already at the stage of inflorescence emergence, and remained under full vegetative development until $60 \mathrm{DAD}$, when they started the reproductive phase, and when the stage of flowering was defined. Bianco et al. (2004)

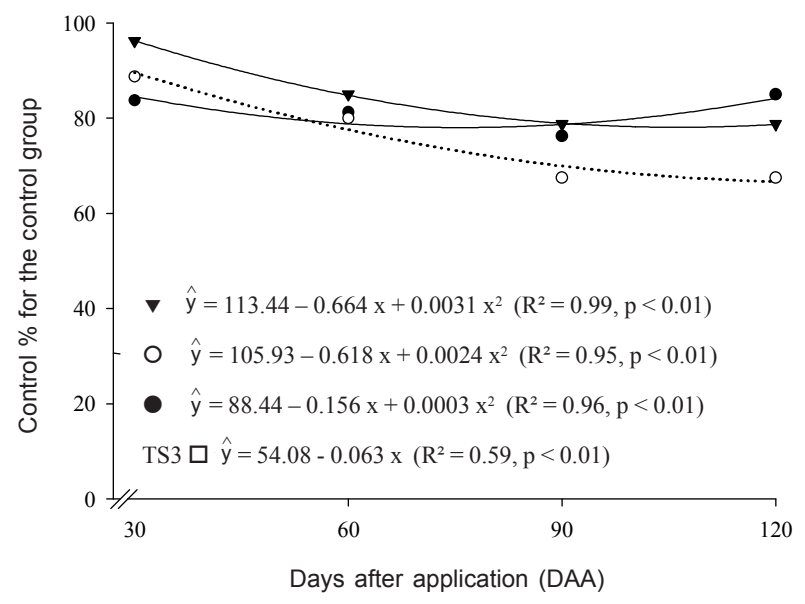

Rates: $1,809.00+510.00+43.50 \mathrm{~g} \mathrm{ha}^{-1}(\boldsymbol{\nabla}), 1,507.50+425.00+$ $36.25 \mathrm{~g} \mathrm{ha}^{-1}(\mathrm{O})$ and $1,386.90+391.00+33.35 \mathrm{~g} \mathrm{ha}^{-1}(\bullet)$.

Figure 9 - Control percentage of Rottboelia spp. for the control, evaluated at 30,60, 90 and 120 DAA of different rates of the formulated mixture diuron + hexazinone + sulfometuronmethyl, for the experiment set up in the month of November. 
observed the flowering of $R$. exaltata before 77 days after emergence (DAE). At 75, 90 and 120 DAD, still in the months of April and May, the Rottboelia spp. plants were at the stage of fruit or seed development (Figure 11).

In the months of June, July and August, at 60, 90 and $120 \mathrm{DAD}$, respectively, the

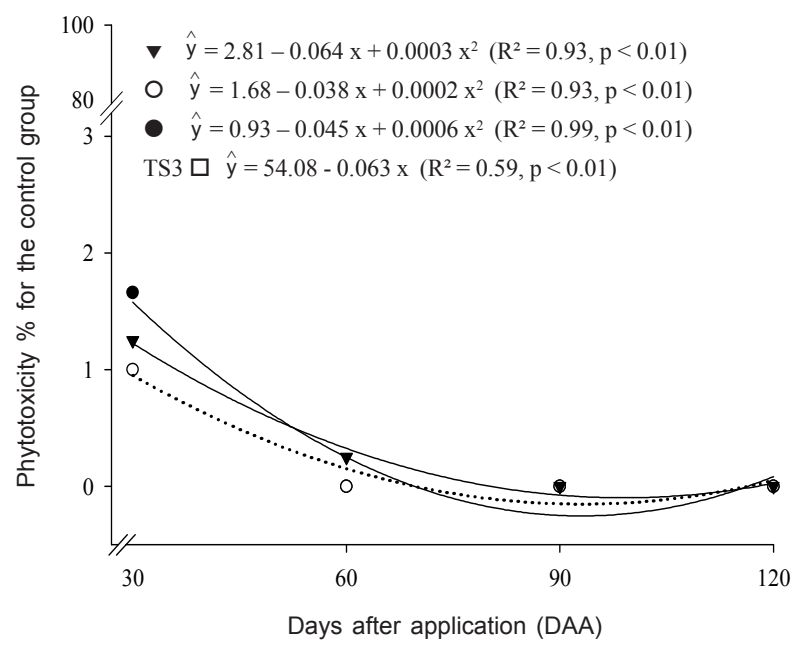

Figure 10 - Percentage of phytotoxicity in the of sugarcane crop, for the control, at 30,60,90 and 120 DAA of different rates of the formulated mixture diuron + hexazinone + sulfometuron-methyl, applied in the months of May $(\boldsymbol{\nabla})$, June (O) and July (○) 2012.

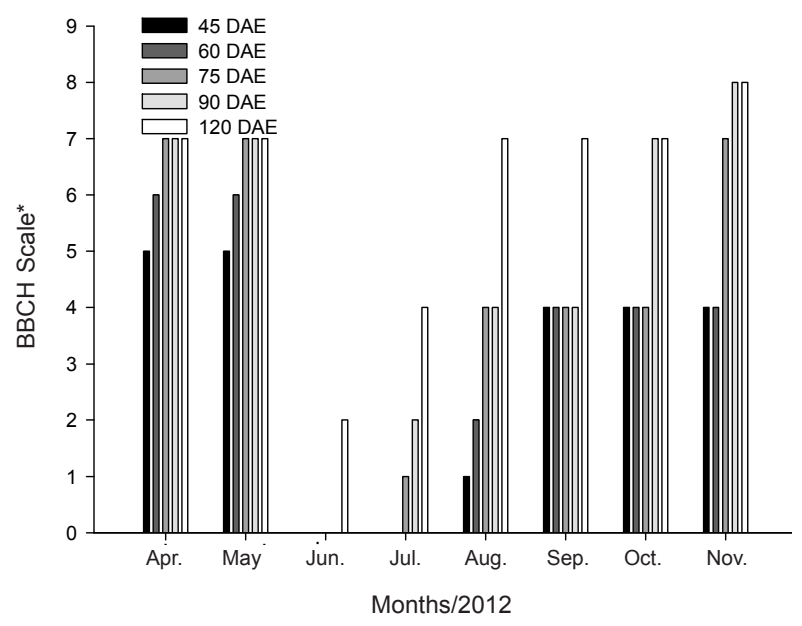

* Hess et al. (1997).

Figure 11 - Phenological stage of Rottboelia spp. based on different months and evaluation times in sugarcane, cultivar RB867515. Tangará da Serra, MT. Harvest 2012/2013.
Rottboelia spp. plants were at the stage of formation of side shoots/tillering, probably as a consequence of the long period of drought. This fact was also evidenced for the Rottboelia spp plants in the months of July and August, at 75 and $45 \mathrm{DAD}$, respectively (Figure 11), when average monthly rainfall was around $55 \mathrm{~mm}$, reflecting the low emergence flow seen in the leaf development stage (Figure 11). In July, at 120 DAD and in August, at 75 and $90 \mathrm{DAD}$, they showed growth stage of vegetative propagation/"booting" (main stem), respectively; in September, from 60 to $90 \mathrm{DAD}$, the same phenological stage occurred (Figure 11).

The stage of development of fruit and seed occurred at 120 DAD, for August, September and October (Figure 11), while in the month of November, at 90 and 120 DAD, Rottboelia spp. was at the phenological stage of fruit or seed maturation; that was the month when the plants of Rottboelia spp. had the highest levels of rainfall (Figure 1).

As regards the emergence of Rottboelia spp., there was no interaction between months and assessment times, and these were significant for population density and height of Rottboelia spp. plants (Tables 2 and 3).

In the evaluation performed at 45 days after desiccation (DAD) of the area, the highest averages were found for population density of Rottboelia spp. These were the desiccations carried out in the months of August, September, October and November, with averages of 576.44, 432.88, 443.00, and 512.89 plants $\mathrm{m}^{-2}$, respectively, which did not differ among themselves. Lower population density was found with the desiccation held in the months of June and July, i.e. there was no emergence of Rottboelia spp. in these months (Table 2), because of the low levels of rainfall observed in the region of Tangará da Serra - MT (Figure 1). According to Dallacort et al. (2011), the months of June, July and August are the most critical for the region, thereby precluding the adequate development of any species.

Similarly to what occurred at 45 DAD, at 60 DAD there was no emergence of Rottboelia spp. in the months of June and 
Table 2 - Population density (plants $\mathrm{m}^{-2}$ ) of Rottboelia spp. based on different months and evaluation times in sugarcane, cultivar RB867515. Tangará da Serra, MT. 2012/2013 Harvest

\begin{tabular}{|l|c|c|c|c|c|}
\hline \multirow{2}{*}{ Month } & \multicolumn{5}{|c|}{ Days after desiccation (DAD) } \\
\cline { 2 - 6 } & 45 & 60 & 75 & 90 & 120 \\
\hline April & $144.25 \mathrm{Ba}$ & $161.00 \mathrm{Ba}$ & $212.00 \mathrm{Ca}$ & $169.50 \mathrm{Ca}$ & $60.33 \mathrm{Da}$ \\
\hline May & $257.25 \mathrm{Bb}$ & $146.00 \mathrm{Bc}$ & $792.00 \mathrm{Aa}$ & $68.67 \mathrm{Cc}$ & $359.78 \mathrm{Cb}$ \\
\hline June & $0.00 \mathrm{Cb}$ & $0.00 \mathrm{Cb}$ & $0.00 \mathrm{Db}$ & $0.00 \mathrm{Cb}$ & $787.92 \mathrm{Aa}$ \\
\hline July & $0.00 \mathrm{Cc}$ & $0.00 \mathrm{Cc}$ & $444.44 \mathrm{Ba}$ & $306.11 \mathrm{Bb}$ & $555.56 \mathrm{Ba}$ \\
\hline August & $443.00 \mathrm{Ab}$ & $358.67 \mathrm{Ab}$ & $557.33 \mathrm{Ba}$ & $555.67 \mathrm{Aa}$ & $364.44 \mathrm{Cb}$ \\
\hline September & $432.88 \mathrm{Aa}$ & $360.44 \mathrm{Aa}$ & $213.67 \mathrm{Cb}$ & $490.67 \mathrm{Aa}$ & $424.67 \mathrm{Ca}$ \\
\hline October & $576.44 \mathrm{Aa}$ & $422.22 \mathrm{Ab}$ & $403.33 \mathrm{Bb}$ & $394.34 \mathrm{Bb}$ & $209.33 \mathrm{Dc}$ \\
\hline November & $512.89 \mathrm{Aa}$ & $226.92 \mathrm{Ab}$ & $240.33 \mathrm{Cb}$ & $101.00 \mathrm{Cb}$ & $104.45 \mathrm{Db}$ \\
\hline
\end{tabular}

Means followed by the same letter, uppercase in the column and lowercase in the row, do not differ by the Scott-Knott test ( $<<0.05$ ). CV $($ months $)=39.44 \%$ and $\mathrm{CV}$ (times) $=2975 \%$.

Table 3 - Plant height (m) for Rottboelia spp. according to different months and evaluation times in the sugarcane, cultivar RB867515. Tangará da Serra, MT. 2012/2013 Harvest

\begin{tabular}{|l|c|c|c|c|c|}
\hline \multirow{2}{*}{ Month } & \multicolumn{5}{c|}{ Days after desiccation (DAD) } \\
\cline { 2 - 6 } & 45 & 60 & 75 & 90 & 120 \\
\hline April & $0.35 \mathrm{Bc}$ & $0.57 \mathrm{Bb}$ & $0.94 \mathrm{Ca}$ & $0.94 \mathrm{Da}$ & $0.93 \mathrm{Ea}$ \\
\hline May & $0.33 \mathrm{Bb}$ & $0.44 \mathrm{Cb}$ & $0.94 \mathrm{Ca}$ & $0.48 \mathrm{Fb}$ & $0.50 \mathrm{Fb}$ \\
\hline June & $0.00 \mathrm{Db}$ & $0.00 \mathrm{Db}$ & $0.00 \mathrm{Fb}$ & $0.00 \mathrm{Hb}$ & $0.26 \mathrm{Ga}$ \\
\hline July & $0.00 \mathrm{Dc}$ & $0.00 \mathrm{Dc}$ & $0.12 \mathrm{Fc}$ & $0.30 \mathrm{~Gb}$ & $1.12 \mathrm{Da}$ \\
\hline August & $0.17 \mathrm{Cd}$ & $0.29 \mathrm{Cd}$ & $0.50 \mathrm{Ec}$ & $0.65 \mathrm{~Eb}$ & $0.96 \mathrm{Ea}$ \\
\hline September & $0.23 \mathrm{Ce}$ & $0.40 \mathrm{Cd}$ & $0.69 \mathrm{Dc}$ & $1.15 \mathrm{Cb}$ & $1.47 \mathrm{Ca}$ \\
\hline October & $0.30 \mathrm{Be}$ & $0.69 \mathrm{Bd}$ & $1.34 \mathrm{Bc}$ & $1.51 \mathrm{Bb}$ & $1.80 \mathrm{Ba}$ \\
\hline November & $0.65 \mathrm{Ad}$ & $1.48 \mathrm{Ac}$ & $1.69 \mathrm{Ab}$ & $1.81 \mathrm{Ab}$ & $2.15 \mathrm{Aa}$ \\
\hline
\end{tabular}

Means followed by the same letter, uppercase in the column and lowercase in the row, do not differ by the Scott-Knott test ( $\mathrm{p}<0.05)$.CV (months) $=19.34 \%$ and CV (times) $=15.25 \%$.

July. In addition to low levels of rainfall, some factors, such as soil texture and sowing depth, may have influenced the number of emerged seedlings of $R$. exaltata, and greater sowing depths have reduced the emergence of the species (Monquero et al., 2012). The highest means of population density were found with the desiccation held in the months of August, September, October and November, which did not differ among themselves, with means of $358.67,360.44,422.22$ and 226.92 plants $\mathrm{m}^{-2}$, respectively (Table 2).

At 75 DAD, the highest average population density of Rottboelia spp. was found in the month of May, with 792.00 plants $\mathrm{m}^{-2}$, significantly differing from the other months. The means of $444.44,557.33$ and 403.33 plants $\mathrm{m}^{-2}$, relative to the months of
July, August and October, did not differ among themselves. In this evaluation, there was still no emergence of Rottboelia spp. for the month of June, as a result of low rainfall levels (Table 2), a fact that may compromise the germination or emergence of Rottboelia spp. seeds, and justifies the fact that water availability is essential for germination (Silva et al., 2009).

Another factor that is considered to be essential in the germination of Rottboelia spp. is temperature: temperatures in the range of $25{ }^{\circ} \mathrm{C}$ yield higher germination percentage; below $10{ }^{\circ} \mathrm{C}$, seeds become dormant, without germination; and at $30^{\circ} \mathrm{C}$ or higher, germination percentage is reduced, causing physiological damage in seeds (Silva et al., 2009). Between the months of April 2012 
to March 2013, maximum temperatures were above $30{ }^{\circ} \mathrm{C}$, but the lowest minimum temperature was observed in the month of July, at $10{ }^{\circ} \mathrm{C}$ (Figure 1).

In the evaluation performed at 90 DAD, higher densities of Rottboelia spp. were found in the months of August and September, with means of 555.67 and 490.67 plants $\mathrm{m}^{-2}$, respectively, which did not differ among themselves. The lowest means for population density were found in April, May, June and November, with $169.50,68.67,0.00$ and 101.00 plants per $\mathrm{m}^{-2}$, respectively, as the germination of Rottboelia spp. had not occurred yet in the month of June (Table 2). For high density of weeds, such as the species Urochloa brizantha, there is competition against sugarcane for the same factors, such as water, light, $\mathrm{CO}_{2}$ and especially nutrients, thus resulting in a reduction of the leaf concentration of macronutrients, which decreases the yield of stems and leaf area (Galon et al., 2012).

In the evaluation performed at $120 \mathrm{DAD}$, the highest average population density of Rottboelia spp. was found in the month of June, with 787.92 plants $\mathrm{m}^{-2}$; however, the lowest average density was found in the months of April, October and November, with 60.33, 209.33 and 104.45 plants $\mathrm{m}^{-2}$ (Table 2).

Table 3 shows the relationship between height of Rottboelia spp. plants as a function of assessment times. At 45 and 60 DAD, the highest average height of Rottboelia spp. plants was found in the month of November: 0.65 and $1.48 \mathrm{~m}$, respectively. The lowest average plant height for Rottboelia spp. was found in the months of June and July, when there was plant emergence (Table 3), as a result of low rainfall rates in the region of Tangará da Serra - MT (Figure 1).

In the evaluation performed at $75 \mathrm{DAD}$, the greatest height of Rottboelia spp. was observed in the month of November $(1.69 \mathrm{~m})$, and there was a significant difference compared with the remaining months. The lowest mean height of Rottboelia spp. was found in the months of June and July, with 0.0 and $0.12 \mathrm{~m}$, respectively, given the absence of emergence at 45 and 60 DAD (Table 3). At 90 DAD, the largest height of Rottboelia spp. Was observed in the month of November $(1.81 \mathrm{~m})$, which showed a significant difference compared with the remaining months. There was the smallest average height of Rottboelia spp. in July, $0.30 \mathrm{~m}$, followed by the month of June, when the germination of plants had not occurred yet, as a result of the period of low rainfall rates (Figure 1).

In the last evaluation, at $120 \mathrm{DAD}$, plants evaluated in the month of November achieved the greatest heights, $2.15 \mathrm{~m}$, and this month differed significantly from the others, followed by October, when plants had the height of $1.80 \mathrm{~m}$ (Table 3). The rapid development of Rottboelia spp. plants, such as in root and shoot formation, is due to its ability to accumulate phytomass, thus favoring its domination in space, because of the higher rate of absorption of water and nutrients, making them competitive against agricultural crops (Carvalho et al., 2005). The lowest heights of Rottboelia spp. plants were found in the month of June, $0.26 \mathrm{~m}$, as a consequence of the absence of rainfall in this month (Figure 1).

Considering the above, it is concluded that controls above $80.00 \%$ were found in the application held in the month of November, at 30 and 60 DAA, regardless of the dose in use. In applications carried out in the other periods of the year (April, May, June, July, August, September and October), there were no satisfactory controls (<80\%) of Rottboelia spp. All treatments were selective for the sugarcane cultivar RB867515. The tests set up in the months of August, September, October and November showed the highest population density at 45 and 60 DAE: between 358 and 576 plants $\mathrm{m}^{-2}$. The month of November was the one that provided the greatest height in all evaluation times, ranging from 0.65 to $2.15 \mathrm{~m}$.

\section{ACKNOWLEDGMENT}

The authors would like to thank the Mato Grosso Research Foundation (FAPEMAT) for the financial support.

\section{LITERATURE CITED}

AGRITEMPO. - Sistema de Monitoramento

Agrometereológico. <http://www.agritempo.gov.br/>. Acesso em: 5 mar. 2013.

Planta Daninha, Viçosa-MG, v. 34, n. 2, p. 229-238, 2016 
BIANCO, S.; BARBOSA JR., A. F.; PITELLI, R. A. Crescimento e nutrição mineral de capim-camalote. Planta Daninha, v. 22, n. 3, p. 375-380, 2004.

CARVALHO, S. J. P. et al. Crescimento e desenvolvimento da planta daninha capim-camalote. Bragantia, v. 64, n. 4, p. 591-600, 2005.

CORREIA, N. M.; LEITE, G. J. Selectivity of the plant growth regulators trinexapac-ethyl and sulfometuron-methyl to cultivated species. Sci. Agric., v. 69, n. 3, p. 194-200, 2012.

DALLACORT, R. et al. Distribuição das chuvas no município de Tangará da Serra, médio norte do Estado de Mato Grosso, Brasil. Acta Sci. Agron., v. 33, n. 2, p. 193-200, 2011.

GALON, L. et al. Disponibilidade de macronutrientes em cultivares de cana-de-açúcar submetidas à competição com Brachiaria brizantha. Ci. Rural, v. 42, n. 8, p. 1372-1379, 2012.

GOMES, L. J. P.; CORREIA, N. M.; PERUSSI, F. J. Eficácia de clomazone, isolado e em mistura, para o controle de Rottboellia exaltata em area de cana-soca. In: CONGRESSO BRASILEIRO DA CIÊNCIA DAS PLANTAS DANINHAS, 28., 2012, Campo Grande. Anais... Viçosa, MG: Sociedade Brasileira da Ciência das Plantas Daninhas, 2012. p. 49-53.

HESS, M. et al. Use of the extended BBCH scale-general for the descriptions of the growth stages of mono and dicotyledonous weed species. Weed Res., v. 37, n. 6, p. 433-441, 1997.

MESCHEDE, D. K. et al. Alteração fisiológica da cana-deaçúcar pela aplicação de glyphosate e sulfumeturon-methyl. Planta Daninha, v. 29, n. 2, p. 413-419, 2011.

MONQUERO, P. A. et al. Profundidade de semeadura, $\mathrm{pH}$, textura e manejo da cobertura do solo na emergência de plântulas de Rottboellia exaltata. Semina: Ci. Agr., v. 33, S1, p. 2799-2812, 2012.
OLIVEIRA, A. R.; FREITAS, S. P. Levantamento fitossociológico de plantas daninhas em áreas de produção de cana-de-açúcar. Planta Daninha, v. 26, n. 1, p. 33-46, 2008.

OLIVEIRA JR., R. S. Mecanismos de ação de herbicidas. In: OLIVEIRA JR., R. S.; CONSTANTIN, J.; INOUE, M. H. Biologia e manejo de plantas daninhas. Curitiba: Omnipax, 2011. p. 141-192.

SANTOS, E. C.; SOUZA, P. A.; CARVALHO, F. T. Eficácia do S-metolachlor associado à ametrina e hexazinona + diuron no controle pré e pós-emergente de plantas daninhas em canade-açúcar. R. Bras. Herbic., v. 10, n. 2, p. 165-175, 2011.

SILVA, C. E. B. et al. Aspectos germinativos de capimcamalote (Rottboellia cochinchinensis). Planta Daninha, v. 27, n. 2, p. 273-281, 2009.

SOCIEDADE BRASILEIRA DA CIÊNCIA DAS PLANTAS DANINHAS - SBCPD. Procedimentos para instalação, avaliação e análise de experimentos com herbicidas. Londrina: $1995.42 \mathrm{p}$.

TIRONI, S. P. et al. Interferência de populações de Brachiaria brizantha na produtividade de cultivares de canade-açúcar. R. Bras. Ci. Agr., v. 8, n. 1, p. 21-26, 2013.

TOLEDO, R. B. E. et al. Manejo de gramíneas no sistema de cana-crua com herbicidas Front, Velpar K e associações com outros herbicidas. In: CONGRESSO BRASILEIRO DA CIÊNCIA DAS PLANTAS DANINHAS, 27., 2010, Ribeirão Preto. Anais... Viçosa, MG: Sociedade Brasileira da Ciência das Plantas Daninhas, 2010. p. 2410-2414.

TOLEDO, R. B. E. et al. Controle de capim-colonião (Panicum maximum) em cana-crua com o herbicida Front quando aplicado em pré-emergência em época seca e em solo argiloso. In: CONGRESSO BRASILEIRO DA CIÊNCIA DAS PLANTAS DANINHAS, 28., 2012, Campo Grande. Anais... Viçosa, MG: Sociedade Brasileira da Ciência das Plantas Daninhas, 2012. p. 258-263. 